DOI: $10.33067 /$ SE.1.2020.5

Stanistaw Kosmynka ${ }^{\star}$

\title{
„Tożsamość pogranicza” hiszpańskich eksklaw Ceuty i Melilli
}

\section{'Border Identity' of Spanish Exclaves Ceuta and Melilla}

\begin{abstract}
The paper shows some aspects of 'border identity' of the two Spanish cities-exclaves: Ceuta and Melilla. It analyses the multicultural dimensions of coexistence between Muslim (Moroccan) and Spanish populations. The article refers to some political, social and economic challenges: Moroccan revindication policy, growing number of Muslim communities, illegal migration, the phenomenon of violent radicalization inspired by the jihadi ideology etc. In this context, the paper focuses on the most important elements of 'the border identity' which are crucial to further the understanding of social problems in these cities. The methodological analysis is based on the integration of historical and system methods as well as scientific research and investigation conducted in Spain. Regarding some integration and inclusion efforts there are still unsolved social and economic problems that may have influence on the coexistence of different ethnocultural communities in the future.
\end{abstract}

Słowa kluczowe: Ceuta, Melilla, Hiszpania, Maroko, migracja, tożsamość

Key words: Ceutra, Melilla, Spain, Morocco, Migration, Identity

\section{Wprowadzenie}

Na przestrzeni ostatnich kilku dekad zauważalny jest w Hiszpanii proces budowy społeczeństwa wielokulturowego. Państwo, z którego niegdyś emigrowały tysiące osób w poszukiwaniu lepszych warunków bytowych, stało się obszarem atrakcyjnym dla przybyszów z różnych regionów świata

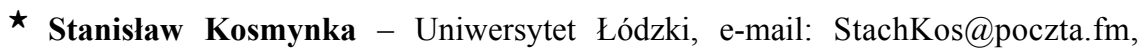
ORCID: 0000-0003-4131-4762. 
- zarówno tych bliższych, jak i dalszych - ludzi motywowanych głównie przesłankami ekonomicznymi, w sposób legalny i nielegalny usiłujących dostać się na Półwysep Iberyjski.

Hiszpania jest od lat państwem tranzytowym, ale również docelowym dla wielu tysięcy imigrantów. Podkreślić należy, że w procesie krystalizacji społeczeństwa wielokulturowego niebagatelną rolę odegrały integracja europejska i rozwój gospodarczy Hiszpanii, które to procesy przyczyniły się do tego, że imigranci stanowią „ponad $12 \%$ populacji kraju, a wskaźniki rozrodczości przybyszów są wyższe niż ludności rodzimej. W takich warunkach, nawet przy restrykcyjnej polityce imigracyjnej i presji na deportacje nielegalnych przybyszów, społeczeństwo hiszpańskie ma już nieodwracalnie wielokulturowy charakter. (...) Przyczynia się do tego również obecność przybyszów reprezentujących całkiem odmienne światy wartości, wierzeń i obyczajów, którzy wymagają jakichś form akomodacji w nowej dla nich przestrzeni społecznej”'. Wielokulturowość społeczeństwa hiszpańskiego jest widoczna szczególnie w dużych miastach, np. w Madrycie, Barcelonie (jej ilustrację stanowi dzielnica Raval), Walencji, Kordobie; wyznacza ją obecność imigrantów i ich kolejnych pokoleń urodzonych już na Półwyspie Iberyjskim, przybyłych m.in. z Maghrebu, Ameryki Łacińskiej, Europy Środkowej, Azji. Podobnie jak w przypadku innych państw Europy Zachodniej i Południowej implementacja wielokulturowości niewątpliwie wzbogaca pod wieloma względami kulturowy i ekonomiczny pejzaż Hiszpanii, ale także rodzi wyzwania związane $\mathrm{z}$ integracją i harmonijnym współistnieniem społeczności, których przedstawiciele nierzadko wywodzą się z odmiennych systemów aksjonormatywnych.

Proces ten od dawna jest widoczny w Ceucie i Melilli, dwóch miastach-eksklawach leżących na terenie Maroka, ale od wieków należących do Hiszpanii ${ }^{2}$. Przypadek tych ośrodków jest szczególny, gdyż, z uwagi na swój status i położenie, leżą one „na styku” Unii Europejskiej i Afryki Północnej. Stanowią one zarazem niezwykłe laboratorium społeczne, na które składają się interakcje kultury europejskiej z muzułmańską. Xavier Ferrer-Gallardo i Ana Planet-Contreras słusznie zauważają, że odkąd w XV w. miasta zostały zdobyte przez Portugalczyków i Hiszpanów, stanowią one symboliczną linię demarkacyjną między islamem a chrześcijaństwem³ ${ }^{3}$

${ }_{1}$ M. Biernacka, Hiszpania wielokulturowa. Problemy z odmiennościa, Scholar, Warszawa 2012, s. 9.

2 Melilla została zdobyta przez Hiszpanów w XV w., Ceuta zaś trafiła pod ich panowanie w XVII w.

3 X. Ferrer-Gallardo, A. Planet-Contreras, Cetua and Melilla: Euro-African Borderscapes, „AGORA” nr 4/2012, s. 32. Por. P. Gold, Europe or Africa?: A Contemporary 
Gdy w 1986 r. Hiszpania przystąpiła do Wspólnoty Europejskiej, miasta te automatycznie stały się ośrodkami granicznymi jednoczącej się Europy. Procesy w nich zachodzące obrazują zarazem krystalizację i funkcjonowanie „tożsamości pogranicza”, skupiającej szereg problemów kulturowych, społecznych i ekonomicznych. Zagadnienie to jest szczególnie ciekawe w odniesieniu do hiszpańskiego społeczeństwa, którego charakter określa w tak dużym stopniu tożsamość grup lokalnych, kluczowa dla zrozumienia specyfiki zamieszkujących te ziemie zbiorowości. Celem artykułu jest diagnoza wyzwań społecznych w kontekście „tożsamości pogranicza”, określających od lat funkcjonowanie Ceuty i Melilli w ramach państwa hiszpańskiego. Analiza tu zawarta uwzględnia dylematy koegzystencji grup odmiennych etnokulturowo i koncentruje się na odpowiedzi na pytanie, $\mathrm{w}$ jakim zakresie stanowią one wyznaczniki separacji społeczno-kulturowej oraz pozostają determinantem tożsamości mieszkańców obydwu miast. Ramy artykułu pozwalają jedynie na zasygnalizowanie najważniejszych kwestii spośród niezmiernie szerokiego spektrum różnorodnych uwarunkowań takiego, a nie innego modelu koegzystencji odmiennych nacji i wynikających zeń wyzwań.

Implikuje to potrzebę wykorzystania interdyscyplinarnego wachlarza metod. W przeprowadzonej analizie pomocna okazała się integracja metody historycznej - szczególnie w kontekście uchwycenia relacji przyczynowo-skutkowych krystalizacji określonych mechanizmów, oraz systemowej, pozwalającej na ujęcie omawianych zagadnień jako powiązanego zespołu elementów, w ramach którego uwaga skupia się zarówno na ich częściach składowych, jak i wzajemnych korelacjach. Diagnoza omawianej problematyki okazała się możliwa w dużym stopniu także dzięki wyjazdom studyjnym w ośrodkach edukacyjnych, społecznych i kulturowych Ceuty i Melilli oraz Andaluzji (Asociación Centro Islámico w Granadzie, Centro Cultural al Idrissi w Ceucie, Centro Educativo Cultural Islámico w Melilli), jak również prowadzonym tam wywiadom eksperckim, m.in. z prof. Javierem Jordanem z Uniwersytetu w Granadzie.

Kwestie społecznych i kulturowych wyzwań, będących udziałem Ceuty i Melilli, nie są często podejmowane przez polskich uczonych. Zagadnienie wielokulturowości Hiszpanii jest prezentowane m.in. w pracach Mai Biernackiej. Kwestie migracji z Afryki do Europy przez Ceutę, statusu tego miasta i obecnych w nim podziałów etnicznych obejmują badania Tomasza Ferenca. W o wiele szerszym zakresie problematyka dotycząca tożsamości Ceuty i Melilli na tle stosunków hiszpańsko-marokańskich jest uwzględniana przez autorów hiszpańskich, takich jak np.: Alejandro

Study of the Spanish North Africa Enclaves of Ceuta and Melilla, Liverpool University Press, Liverpool 2000, s. 34-37. 
del Valle, Carmen González-Enríquez, Ángel Perez González, José María Lopez Bueno, Xavier Ferrer-Gallardo, Ana Planet-Contreras, Fernando Ramos. Jeśli chodzi o znaczenie tych ośrodków dla stosunków hiszpańsko-marokańskich oraz problematykę mającej tam miejsce radykalizacji salafickiej, należy również wspomnieć o ekspertach hiszpańskiego Królewskiego Instytutu Elcano: Fernando Reinaresie, Caroli Garcíi-Calvo, Álvaro Vicente.

W niniejszej analizie pogranicze jest rozumiane jako „obszar - terytorium, na którym ma miejsce określony typ współżycia dwóch lub więcej grup kulturowych, najczęściej etnograficznych, językowych, wyznaniowych, narodowościowych"4. Podkreślając, że pogranicze nie jest kulturowo homogeniczne, Jerzy Nikitortowicz zauważa, że bywa ono postrzegane jako swoisty proces oraz jego rezultat dotyczący społecznych interakcji: „W przejściu od monologu do dialogu kultur, od dominacji stereotypów i uprzedzeń do wzajemnego zrozumienia, negocjacji i dbałości o wspólny spadek kultury pogranicza. Ludzie w efekcie codziennych kontaktów nabywają umiejętności bycia i takim i takim, mimo cech różniących, przypisujących ich do określonej grupy wyznaniowej czy etnicznej"s. Założenie to, jakkolwiek brzmi nieco idealistycznie, zakłada, że duża częstotliwość wzajemnych interakcji sprzyja poznaniu ,innego” i akceptacji dla odmienności, tożsamość zaś może kształtować wiele źródeł określających autopercepcję i miejsce w lokalnej społeczności, czego dowodzą m.in. przywoływane dalej wyniki badań. Na obraz tak rozumianego pogranicza rzutują interakcje między grupami od dawna zamieszkującymi dane terytorium, znajdującymi się często na styku kultur, a także rezultaty zmian tkanki społecznej, wywołanej np. przez ruchy migracyjne oraz przyrost demograficzny społeczności napływowych o odmiennym rodowodzie etnicznym, zwyczajach, wierzeniach, wartościach.

\section{Ceuta i Melilla w stosunkach hiszpańsko-marokańskich}

Obydwa miasta oraz ich status są od lat powodem animozji hiszpańsko-marokańskich. Władze Maroka wielokrotnie wysuwały żądania przyłączenia tych obszarów, określając je często jako terytoria marokańskie pod obcym panowaniem i traktując ich przynależność do Hiszpanii jako relikt przeszłości kolonialnej - co tym samym uzasadniałoby postulat zmiany ich sytuacji formalno-prawnej ${ }^{6}$. Argumentowały m.in., że ich

4 J. Nikitorowicz, Pogranicze. Tożsamość. Edukacja międzykulturowa, Trans Humana, Białystok 1995, s. 11.

5 Ibidem, s. 13.

6 Por. A. Planet-Contreras, Melilla y Ceuta. Espacios-frontera hispano-marroquies, Servicio de Publicaciones, Melilla 1998, s. 34-52; Relaciones hispano-marroquies: una 
sytuacja przypomina status Hong Kongu lub Makao, a zatem także i te ośrodki wraz z kilkoma wyspami powinna objąć kolejna faza dekolonizacji. Artykuł 42 konstytucji Maroka z 2011 r. odnosi się do „rzeczywistych granic" Królestwa, które w przyszłości powinny być inkorporowane do ojczyzny, co dotyczy także Ceuty i Melilli ${ }^{7}$, traktowanych w takim ujęciu de facto jako terytoria okupowane. W 2002 r. król Maroka Muhammad VI podkreślił potrzebę podjęcia dialogu z Madrytem na temat weryfikacji statusu miast. Z kolei wizyta w Ceucie i Melilli hiszpańskiego króla Juana Carlosa w 2007 r. wywołała ostre protesty władz w Rabacie i nasilenie postulatów rewindykacyjnych. Hiszpania stanowczo, co oczywiste, odrzuca marokańskie roszczenia, uważając oba ośrodki za integralną część terytorium państwa hiszpańskiego. Nie obejmował ich hiszpański protektorat w Afryce Północnej (1912-1956), co poskutkowało pozostaniem obu miast w granicach Hiszpanii pomimo uzyskania przez Maroko niepodległości. W okresie dyktatury gen. Francisco Franco traktowano je jako obszary wchodzące w skład Andaluzji. Stanowisko w sprawie statusu Ceuty i Melilli zajęła nawet ONZ, nie uznając ich za terytoria, które by mogły być objęte procesem dekolonizacji - wedle wykładni prawnej należały one nieprzerwanie przez długi czas do Królestwa Hiszpanii, zanim Maroko ukonstytuowało się jako samodzielny i niepodległy byt państwowy.

Pomimo animozji na tym tle na przestrzeni ostatnich kilkunastu lat obserwujemy rozwój współpracy strategicznej obydwu państw, podyktowanej przede wszystkim potrzebą zwalczania terroryzmu dżihadystycznego, będącego kreatorem zagrożeń dla bezpieczeństwa po obu stronach Cieśniny Gibraltarskiej ${ }^{8}$. Maroko jest też ważnym partnerem USA w walce $\mathrm{z}$ ekstremizmem salafickim, a przecież stabilizacja sytuacji $\mathrm{w}$ regionie jest istotnym aspektem bezpieczeństwa międzynarodowego. Należy wszak pamiętać, że strategia antyterrorystyczna Hiszpanii musi w dużym zakresie koncentrować się na minimalizowaniu prawdopodobieństwa zamachu przeprowadzonego przez ekstremistów wywodzących się z Maghrebu, a szczególnie z Maroka. Oba państwa pozostają dla siebie ważnymi partnerami gospodarczymi. Ich współpraca obejmuje także walkę ze zorganizowaną przestępczością i kontrolę graniczną. Jest ona potrzebna nie tylko ze względu na problem nielegalnych prób przekraczania granic, ale także na trwający od lat proceder przemytu dóbr i nielegalny obrót towarami,

vecindad en construcción, red. A. Planet Contreras, F. Ramos, Ediciones del Oriente y del Mediterráneo, Madrid 2005.

7 A. del Valle, Ceuta, Melilla, Chafarinas, Vélez y Alhucemas: tomar la iniciativa, Real Instituto Elcano, „ARI” 20 de diciembre de 2011, s. 5.

8 Więcej w: S. Kosmynka, The Role of Moroccan Salafist Radicalism in Creating Threat to Spain's Security, „Politeja” nr 42/2016, s. 164-188. 
którym to praktykom sprzyjały wysokie wskaźniki ubóstwa i bezrobocia, będące udziałem szczególnie młodych Marokańczyków9

Z drugiej strony w odniesieniu do „szarej strefy” i dochodów płynących z przemytu pojawia się czasami w hiszpańskich mediach eufemistyczne określenie „nietypowy handel” (comercio atípico), odnoszące się de facto do jego tolerowania do pewnego stopnia przez strony hiszpańską i marokańską - w 2012 r. kwoty płynące z tego procederu były szacowane na ok. $500 \mathrm{mln}$ euro rocznie ${ }^{10}$. Przemyt i "szara strefa" stanowią ważne wsparcie ekonomiczne dla sąsiadującej z Melillą marokańskiej prowincji Nador. Trzeba dodać, że ośrodki te w pierwszej dekadzie XXI w. stały się obszarem zintensyfikowanej aktywności grup przestępczych, zajmujących się "praniem brudnych pieniędzy” i handlem narkotykami, zwłaszcza haszyszem pochodzącym z marokańskiego regionu Rif $^{11}$. Ceuta i Melilla, będąc niejako „bramą” do Hiszpanii, a zarazem Unii Europejskiej, są miastami szczególnie narażonymi na przemyt substancji psychoaktywnych. Stąd też współpraca hiszpańsko-marokańska jest determinowana wspólnymi wyzwaniami w zakresie utrzymywania bezpieczeństwa, pozostając ważnym elementem polityki UE wobec Afryki Północnej.

\section{Kwestia ochrony granic}

Jak wspomniano, granice Ceuty i Melilli są zarazem granicami Unii Europejskiej. Jest zatem oczywiste, że odgrodzony barierami i zasiekami obszar jawi się jako swoista „ziemia obiecana” nie tylko dla wielu obywateli Maroka, ale także dla osób pochodzących z innych zakątków Afryki. Problem nielegalnej imigracji nasilił się od lat 90 . XX w., kiedy Ceuta i Melilla stały się miastami tranzytowymi dla imigrantów i uchodźców z Afryki Północnej i Subsaharyjskiej, podążających na kontynent euro-

9 Na przykład w 2015 r. wskaźniki bezrobocia wynosiły aż 38\% w Ceucie i 32\% w Melilli. W 2018 r. sytuacja nieco poprawiła się, choć i tak wartości te były wysokie: wynosiły one, kolejno, 30 i $24 \%$. Bezrobocie wśród osób młodych jest znacznie wyższe (50 i 60\%). Por.: Ceuta y Melilla ya están marroquinizadas y van hacia el choque con España, „El Brief de Actuall”, https:/www.actuall.com/democracia/ceuta-y-melilla-yaestan-marroquinizadas-y-van-hacia-el-choque-con-espana/ (dostęp 14.08.2019); P. Moral, Ceuta y Melilla, la excepción española, https://elordenmundial.com/ceuta-y-melilla-laexcepcion-espanola/ (dostęp 14.08.2019).

10 B. Mesa García, Ceuta y Melilla: una visión de futuro, Instituto Español de Estudios Estratégicos, „Documento de Opinión” No. 3/2012, s. 5.

11 T. Blickman, Morocco and Cannabis. Reduction, containment or acceptance, „Drug Policy Briefing” 2017, https:/www.researchgate.net/publication/316104129_Morocco_and_Cannabis_Reduction_containment_or_acceptance (dostęp 20.04.2019). 
pejski. W 1995 r. rozbudowano i ufortyfikowano zabezpieczenia mające strzec teren miast przed napływem nielegalnych imigrantów. W $1999 \mathrm{r}$. władze Hiszpanii, korzystając ze wsparcia Unii Europejskiej (tak np. tylko w latach 1995-2000 UE pokryła 75\% kosztów przeznaczonych na uszczelnianie granic Ceuty ${ }^{12}$ ), zdecydowały o podjęciu działań służących zabezpieczeniu miast i udoskonaleniu systemu ich monitoringu w celu powstrzymania napływu nielegalnej imigracji ${ }^{13}$. System zapór okalających miasta ma udaremnić próby przedostania się na ich teren, a jednocześnie w sposób symboliczny i dosłowny oddziela od Maroka obszar należący do Hiszpanii. Znamienne jest, że porównywano je nawet do muru berlińskiego ${ }^{14}$.

Szereg z tych przedsięwzięć zostało zrealizowanych w ramach Zintegrowanego Systemu Kontroli Zewnętrznej (Integrated System of External Surveillance, SIVE), obejmującego także wody terytorialne Hiszpanii. Ceuta i Melilla są określane jako najsilniej strzeżone strefy graniczne Unii Europejskiej ${ }^{15}$. Należy pamiętać, że na przestrzeni lat, w czasie prób przedostania się na teren miast, a zarazem UE, niejednokrotnie dochodziło do tragicznych wydarzeń - tak np. w sierpniu 2005 r., podczas próby sforsowania zasieków i barier okalających Melillę, śmierć poniósł siedemnastoletni obywatel Kamerunu, na jesieni tego samego roku zginęło kilkanaście innych osób, setki kolejnych usiłowały zaś sforsować fortyfikacje i przedostać się na obszar UE. Wiele osób, które wtargnęły na teren Ceuty i Melilli bez wymaganych pozwoleń, zostało wydalonych. Wedle szacunków w samym tylko 2017 r. do Ceuty przedostało się w sposób nielegalny ok. 2250 imigrantów $^{16}$.

Pomimo nakładu dużych środków finansowych na udoskonalanie logistycznego systemu zabezpieczeń problem nadal istnieje. W sierpniu 2019 r. do Ceuty starało się przedostać 250 osób, a w towarzyszących temu starciach zostało rannych 11 funkcjonariuszy hiszpańskiej Straży Obywatelskiej (Guardia Civil). Wedle doniesień Amnesty International w tego typu sytuacjach dochodzi niestety do naruszania praw człowieka i rozmaitych nadużyć. Wśród nich należy wymienić np. przypadki odsyłania uchodźców na stronę marokańską, a następnie deportacji bez zapewnienia

12 S. Saddiki, World of Walls. The Structure, Roles and Effectiveness of Separation Barriers, Open Book Publishers, Cambridge 2017, s. 86.

13 P. Soddu, Ceuta and Melilla: Security, Human Rights and Frontier Control, „Culture and Society" 2006, s. 212.

14 B. Casella, Morocco, Ceuta and Melilla: a failed immigration policy, „Mediterranean Affairs" December 3, 2014, s. 11.

15 X. Ferrer-Gallardo, A. Planet-Contreras, op. cit., s. 32.

162.250 inmigrantes entraron en Ceuta ilegalmente desde Marruecos en 2017, „La Gaceta" 5 de enero de 2018. 
im odpowiedniej pomocy humanitarnej ${ }^{17}$. W raporcie $z$ jesieni $2016 \mathrm{r}$. informowano o przypadkach dyskryminacji zatrzymanych osób ze względu na ich narodowość, a także o odbiegających od wymaganych standardów warunkach panujących w przeznaczonych dla imigrantów Ośrodkach Pobytu Tymczasowego (Centros de Estancia Temporal para Inmigrantes, CETI ${ }^{18}$. W CETI w Ceucie pod koniec sierpnia 2019 r. przebywało ok. 650 osób. Krytyce poddawane były również i inne praktyki; kwestionowano np. zasadność używania przez siły porządkowe gazu łzawiącego. Problemy związane $z$ nielegalnym przekraczaniem granic są udziałem głównie osób wywodzących się z regionu Afryki Subsaharyjskiej. Powstrzymanie fal imigracji właśnie $z$ tego regionu stało się główną przesłanką tzw. Planu Afryka, przyjętego przez władze Hiszpanii w latach 2005-2008.

Kryzys migracyjny z 2005 r. doprowadził do politycznej i wojskowej intensyfikacji współdziałania Madrytu i Rabatu w zakresie uszczelnienia granic, do czego zaangażowane zostały specjalne jednostki z obydwu państw, co wpłynęło na dalszą militaryzację stref. Wysiłki te okazały się skuteczne jedynie częściowo; w kolejnych latach, jak wspomniano, nadal notowano częste próby nielegalnego przekroczenia granic miast. Nie bez wpływu okazały się wydarzenia tzw. arabskiej wiosny oraz mający miejsce kryzys migracyjny, którego skutkiem był masowy exodus uchodźców z Afryki i Bliskiego Wschodu do Europy. Skalę tego problemu obrazują poniższe dane. Tak np. w 2011 r., wedle danych hiszpańskiego Ministerstwa Spraw Wewnętrznych, w Ceucie i Melilli odnotowano ponad 3300 prób nielegalnego przekroczenia granicy, głównie przez imigrantów wywodzących się z Afryki Subsaharyjskiej ${ }^{19}$. W 2013 i 2014 r. usiłowali tam również przedostać się uchodźcy z pogrążonej w konflikcie zbrojnym Syrii oraz z Sahelu. Do połowy 2018 r. ponad 4 tys. imigrantów dostało się nielegalnie na teren Ceuty i Melillii ${ }^{20}$. Dane te obrazują, jak ważnym i stale aktualnym przedsięwzięciem pozostaje ochrona granic na południowej flance UE, a zarazem rodzą pytania o skutki społeczne i kulturowe tych procesów związane ze współistnieniem różnych społeczności.

${ }_{17}$ T. Ferenc, Ceuta - afrykańskie wrota do Europy, „Pogranicze - Polish Borderlands Studies" t. 6, nr 2/2018, s. 142.

18 Zob. Ceuta y Melilla: un teritorio sin derechos para personas migrantes y refugiadas, Amnistía Internacional, 26 de noviembre de 2016, https://www.es.amnesty.org/ en-que-estamos/noticias/noticia/articulo/ceuta-y-melilla-un-territorio-sin-derechos-parapersonas-migrantes-y-refugiadas/ (dostęp 17.08.2019).

19 X. Ferrer-Gallardo, A. Planet-Contreras, op. cit., s. 34.

20 S. Saddiki, op. cit., s. 123. 


\section{Pejzaż społeczny Ceuty i Melilli}

Do 1868 r. Marokańczycy nie mogli osiedlać się na terenie tych dwóch miast. Dodajmy, że we wspomnianych wcześniej marokańskich roszczeniach pojawiała się również kwestia demograficzna: rosnący odsetek populacji Ceuty i Melilli stanowią Marokańczycy i muzułmanie - społeczności, które wedle władz Maroka od tak dawna doświadczają dyskryminacji i marginalizacji ${ }^{21}$. Wśród liczącej ponad 85 tys. mieszkańców Ceuty muzułmanie stanowią ponad $43 \%$ populacji. Porównywalną liczbę mieszkańców ma Melilla (w tym ponad 51\% wyznawców islamu ${ }^{22}$. Od lat zaznacza się proces „marokanizacji” tych ośrodków, do którego przyczynia się rosnący demograficznie odsetek wyznawców islamu. Jest on wynikiem przyrostu naturalnego wśród tej społeczności, a także napływu Marokańczyków z sąsiednich prowincji (Tetuan, Nador ${ }^{23}$ ), którzy znajdują zatrudnienie w sektorze budownictwa oraz - głównie kobiety - w zakresie pomocy w prowadzeniu domu oraz innych usługach.

$\mathrm{Na}$ wzrost populacji muzułmanów rzutuje też znaczna liczba osób, które mogą przebywać na terenie miast tylko czasowo, ale są potrzebne stronie hiszpańskiej, gdyż „Maroko oferuje tanią siłę roboczą” ${ }^{24}$. Postępujący proces starzenia się populacji hiszpańskiej oraz niską dzietność rodzin hiszpańskich w obydwu miastach, a szczególnie w Melilli, Alejandro Macarrón nazywa wprost „samobójstwem demograficznym”. Tak np. w Melilli blisko połowę mieszkańców stanowią maghrebscy muzułmanie; w 2008 r. 34\% dzieci, które przyszły tam na świat, miało marokańskie matki ${ }^{25}$. Analizy z 2015 r. wskazują, że ok. 50\% populacji miasta stanowili Arabowie i Berberowie ${ }^{26}$. Ponadto wielu mieszkających w Ceucie i Melilli Hiszpanów w ostatnich latach przeprowadziło się na drugą stronę Cieśniny Gibraltarskiej. Procesy o charakterze demograficznym pojawiały się zatem wielokrotnie w prowadzonym przez władze Maroka dyskursie rewindykacyjnym, dowodzącym, że mają one swe przełożenie na filary toż-

${ }^{21}$ C. González-Enríquez, Á. Pérez González, Ceuta y Melilla: nuevos elementos en el escenario, Real Instituto Elcano, „ARI” 4 de diciembre de 2008, s. 5.

${ }^{22}$ Dane za: La población musulmana en España, Fundación „Forum Libertas” 29 de agosto de 2017.

${ }^{23}$ Osoby urodzone w tych prowincjach nie muszą posiadać wizy, aby legalnie dostać się do Ceuty i Melilli.

${ }^{24}$ B. Mesa García, op. cit., s. 8 (tłum. własne).

25 A. Macarrón, Melilla y nuestro suicidio demográfico, „Libertad digital” 6 de septiembre de 2010, http://www.libertaddigital.com/opinion/alejandro-macarron/melilla-ynuestro-suicidio-demografico-56115/ (dostęp 30.03.2013).

${ }^{26}$ Ceuta y Melilla ya están..., op. cit. 
samościowe stale zwiększającej się liczby ich mieszkańców o rodowodzie marokańsko-muzułmańskim.

Starając się powstrzymać negatywne dla Hiszpanii procesy, sprawujący władzę w miastach politycy Juan Vivas i Juan José Imbroda, reprezentujący konserwatywną Partię Ludową (Partido Popular), na początku 2019 r. wystąpili z inicjatywą zmiany przepisów dotyczących nadawania hiszpańskiego obywatelstwa dzieciom imigrantów urodzonych na obszarze Ceuty i Melilli, a więc na terytorium państwa hiszpańskiego. Ocenia się, że każdego roku w rodzinach marokańskich przychodzi na świat ok. 2,5 tys. dzieci ${ }^{27}$. Projekt zmiany przepisów przewidywałby wydłużenie wymaganego okresu legalnego pobytu na terytorium Hiszpanii z roku do dziesięciu lat.

Warto zaakcentować, że, jak dotąd, koegzystencja grup odmiennych kulturowo nie była nacechowana konfliktami i wyraźnymi antagonizmami, pomimo istnienia pewnych obaw i uprzedzeńn ${ }^{28}$. Dotyczyły one m.in. procesu islamizacji społeczności obu miast, a nawet ewentualnej zmiany ich statusu. Obawy hiszpańskiej części populacji są potęgowane również przez fakt wzmożonej aktywności w odniesieniu do Ceuty i Melilli siatek dżihadystycznych, które prowadzą narrację rewindykacyjną i wzywają do odzyskania terenów okupowanych przez „niewiernych”. Dogodne warunki dla oddziaływania przybywających często nielegalnie $z$ terytorium Maroka przedstawicieli nurtów ekstremistycznych, usiłujących przysposobić jednostki do realizacji samobójczych misji, pozostają w dużym stopniu splecione ze wskaźnikami różnych form wykluczenia społecznego, przypadkami przerywania przez młodzież edukacji i kolizji z prawem w ubogich dzielnicach tych miast, co egzemplifikują dziecińce Príncipe Alfonso i La Cañada. Proces ten ilustrują dane: „u schyłku 2014 r. poziom bezrobocia wśród osób poniżej 25. roku życia w Ceucie sytuował się na poziomie aż 72 proc., a w Melilli wynosił 57 proc. Odsetek osób przerywających naukę był także wysoki; wynosił kolejno 40 i 33 proc. $Z$ kolei ok. 24 proc. muzułmanów, którzy wyruszyli z Hiszpanii do Syrii i Iraku, by zaangażować się w strukturach Daesh, pochodziło z Ceuty. Dodajmy, że aż 70 proc. zatrzymanych w Hiszpanii dżihadystów w latach 2013-2014 wywodziło się $z$ tych dwóch miast”29. Nie można lekceważyć aktywności

${ }^{27}$ Ceuta y Melilla plantean negar la nacionalidad española a los hijos de inmigrantes, „Vozpopuli” 17 de febrero de 2019.

${ }_{28}$ Ceuta y Melilla celebran ser un "ejemplo" de convivencia con la fiesta de sacrificio, „El Mundo” 17 de noviembre de 2011.

29 S. Kosmynka, Zapobieganie radykalizacji jako element strategii antyterrorystycznej władz Hiszpanii, w: Międzynarodowe oblicza terroryzmu. Ujęcie interdyscyplinarne, red. T. Domański, Wydawnictwo Uniwersytetu Łódzkiego, Łódź 2017, s. 167-168. Por. Una Universidad busca prevenir que jóvenes de Melilla no caigan en manos del yihadismo, „Melilla Hoy” 19 de enero de 2015; F. Reinares, C. García-Calvo, Á. Vicente, 
przedstawicieli ugrupowań salafickich, takich jak At-Takfir wa-1-hidżra (Wyklęcie i Wygnanie). W odpowiedzi m.in. na te zagrożenia władze hiszpańskie wprowadziły w styczniu 2015 r. Narodowy Plan Strategicznego Walki z Radykalizacją (Plan Estratégico Nacional de Lucha Contra la Radicalización Violenta - PEN-LCRV) pod auspicjami Ministerstwa Spraw Wewnętrznych ${ }^{30}$. Wśród głównych założeń tego kompleksowego projektu znalazły się: monitoring zakładów penitencjarnych, instytucji edukacyjnych oraz ośrodków kultu religijnego w celu minimalizowania ryzyka oddziaływania narracji ekstremistycznej, której efektem bywa, jak wiadomo, zaangażowanie w działalność terrorystyczną.

W ostatnich latach na Uniwersytecie im. Camilo José Cela został przygotowany projekt mający przyczynić się do zapobiegania radykalizacji w dzielnicach Príncipe Alfonso i La Cañada, polegający na sporządzeniu profilu psychologicznego i cech afektywnych osób szczególnie podatnych na tego rodzaju wpływy, co w konsekwencji ułatwić miało przygotowanie specjalnych programów inkluzji społecznej i edukacji adresowanych do młodych muzułmanów. Problem radykalizacji salafickiej i rekrutacji dżihadystycznej w obu miastach jest więc stale poważnym kreatorem wyzwań dla bezpieczeństwa Hiszpanii.

Wielu hiszpańskich autorów, m.in. David Alvarado, prezentuje krytyczny stosunek do polityki władz hiszpańskich, podkreślając negatywne konsekwencje długotrwałego braku właściwej strategii integracji prowadzącej do bezkonfliktowego współistnienia społeczności hiszpańskiej i maghrebskiej. Na przykład w Ceucie w 2000 r. tylko 4\% zdających na studia wyższe było muzułmanami, za to aż ok. $60 \%$ młodzieży przerywało edukację w szkołach ponadpodstawowych - wiele spośród młodych osób weszło następnie na drogę przestępczą, trudniąc się handlem narkotykami i bronią w dzielnicy Príncipe Alfonso w Ceucie oraz Cañada Real w Melilli ${ }^{31}$. Społeczność marokańsko-muzułmańska, z uwagi na zazwyczaj niższe kwalifikacje, rzadziej znajdowała zatrudnienie w sektorze administracji - zajmowała dolne szczeble drabiny stratyfikacji społecznej, co z kolei było wielokrotnie wskazywane przez jej przedstawicieli jako przejaw dyskryminacji tego segmentu populacji oraz jej stygmatyzacji. W zamieszkiwanych przez nich dzielnicach tradycyjnie sporym poparciem cieszą się partie odwołujące się przede wszystkim do elektoratu wyznawców islamu (Coalición por Melilla i Coalición Caballas de Ceuta). W wielu opracowa-

Dos factores que explican la radicalización yihadista en España, Real Instituto Elcano de Estudios Internacionales y Estratégicos, „ARI” 8 de agosto de 2017.

${ }^{30}$ Więcej w: S. Kosmynka, Zapobieganie radykalizacji jako..., op. cit., s. 171-176.

31 D. Alvarado, La yihad a nuestras puertas. La amenaza de Al Qaeda en el Maghreb Islámico, Foca, Madrid 2010, s. 216-217. 
niach zwraca się też uwagę na - skorelowany ze wspomnianymi wcześniej procesami - problem nierówności społecznych. Duże wyzwanie stanowią polaryzacja i rozwarstwienie ekonomiczne między społecznościami muzułmańską i chrześcijańską ${ }^{32}$.

Preambuły statutów autonomicznych (obowiązujących od 1995 r.) zawierają stwierdzenia co do stanowiącej ich podstawę różnorodności kulturowej. Jej akceptację gwarantuje również art. 14 hiszpańskiej ustawy zasadniczej, zakazujący jakiejkolwiek dyskryminacji ze względu na pochodzenie, wyznanie, płeć, światopogląd lub inne kwestie. Jej zapobieganiu mają służyć programy społeczne implementowane na przestrzeni ostatnich dekad przez władze Hiszpanii. Tak np. w Melilli już w latach 80. XX w. wprowadzono w szkołach wiele programów nauczania dwujęzycznych (w hiszpańskim oraz używanym przez ludy berberyjskie języku tamazight). Trzeba pamiętać, że wbrew obiegowym opiniom społeczność muzułmańska nie jest homogeniczna; w Melilli widoczny jej odsetek stanowią wyrażający dążenia autonomiczne Berberowie.

Pomimo deklarowanego poszanowania dla idei wielokulturowości hiszpańscy eksperci zajmujący się omawianą problematyką często zwracają uwagę na problem faktycznej separacji odmiennych etnokulturowo społeczności marokańsko-muzułmańskiej i hiszpańskiej, podkreślając, że w odniesieniu do Ceuty i Melilli należy mówić o ich koegzystencji, nie zaś o integracji ${ }^{33}$. Świadczy o tym np. niewielki odsetek związków egzogamicznych, ograniczona liczba wzajemnych interakcji w dzielnicach, szkołach i innych instytucjach. Jak wspomniano, separacja ta nie ma charakteru silnie antagonistycznego. Pomimo istnienia wielu różnic i odrębnych sfer życia warto podkreślić fakt tolerancji i akceptacji idei i praktyki wielokulturowości, którą kieruje się wielu przedstawicieli obu społeczności. Jednym z przejawów np. tolerancji obyczajowej jest funkcjonowanie w przestrzeni publicznej kobiet noszących muzułmańskie chusty i tych, które nie praktykują takiego zwyczaju ${ }^{34}$. W Melilli za czas wolny od pracy uznane jest muzułmańskie święto Id al-Adha (Święto Ofiarowania). Do kalendarza został też włączony Ramadan. Dodajmy, że w ceremoniach świąt obchodzonych przez muzułmanów niejednokrotnie biorą też udział przedstawiciele władz lokalnych ${ }^{35}$.

${ }^{32}$ Zob. T. Ferenc, op. cit., s. 151-152.

33 C. González-Enríquez, Á. Pérez González, op. cit., s. 6.

34 B. Mesa García, op. cit., s. 9. Por. M. Dominguez Diaz, The struggle to be seen: Muslim-Christian relations and religious (in)visibility at the Hispano-Moroccan borderland, ,Journal of Contemporary Religion” Vol. 33/2018, Issue 3, s. 26-27.

35 J.M. López Bueno, Melilla: lecciones inadvertidas de integración, Real Instituto Elcano, „ARI” 20 de octubre de 2010, s. 7. 
Interesujące badania dotyczące tożsamości wyznających islam mieszkanek Ceuty i Melilli zamieszcza Salam Adlbi Sibai ${ }^{36}$. Odwołując się do modelu teoretycznego akulturacji Johna W. Berry'ego i na podstawie przeprowadzonych z kobietami wywiadów swobodnych, rysuje się tak deklarowana komplementarność źródeł tożsamości: w przywołanym badaniu respondentki często określały się jako Europejki, Hiszpanki, ale i muzułmanki. Podkreślając fakt swego pochodzenia z Ceuty i Melilli, wskazywały na nieadekwatność terminu ,integracja” i praktyki dyskryminacyjne, których doświadczały, oraz na istnienie stereotypów w postrzeganiu wyznawców islamu („nie każdy Arab jest muzułmaninem i nie każdy muzułmanin to Arab"37). Badania te potwierdziły praktykę funkcjonowania odrębności kulturowej i religijnej współistniejących na jednym obszarze społeczności.

\section{Podsumowanie}

Strategiczne położenie Ceuty i Melilli oraz mozaika społeczno-kulturowa ich mieszkańców egzemplifikują złożony charakter procesów zachodzących w regionach wielokulturowych i granicznych, w których ogniskuje się szereg wyzwań określających specyfikę ich istnienia. Kwestie te obejmują zarówno problem braku zrównoważonego rozwoju, ubóstwa i wykluczenia społecznego, dotykającego zwłaszcza niektóre grupy społeczne, jak i poważniejsze zagrożenia wynikające $\mathrm{z}$ radykalizacji ekstremizmem odwołującym się do religii. Nie należy zapominać także o innych problemach wynikających z aktywności sprawców drobnej i zorganizowanej przestępczości czy nielegalnej imigracji. Wyzwania rodzi też sporny status miast, do których pretensje szereg razy wysuwane były przez stronę marokańską. Włoski socjolog Raimondo Strassoldo już na początku lat 80. XX w. zauważył, że postępujący proces integracji europejskiej i zanik wewnętrznych granic doprowadzi wraz $z$ biegiem czasu do intensyfikacji problemów granicznych z państwami i regionami nienależącymi do wspólnoty Starego Kontynentu ${ }^{38}$. Oczywistość i trafność tej diagnozy potwierdzają dobitnie procesy, z którymi mierzyć się musi UE w XXI w.

Przypadek Ceuty i Melilli jest wyjątkowy nie tylko w tym kontekście, ale także w świetle historii stosunków marokańsko-hiszpańskich oraz w szerszym ujęciu - chrześcijańsko-muzułmańskich. Miasta te stanowią

${ }^{36}$ S. Adlbi Sibai, 'Sometimes I'm Spanish and sometimes not': a study of the identity and integration of Spanish Muslim women, „Research in Comparative and International Education" Vol. 5, No. 2/2010.

37 Ibidem, s. 196.

38 Zob. J. Castan Pinos, Identity Challenges Affecting the Spanish Enclaves of Ceuta and Melilla, „Nordlit” No. 13 (1)/2009, s. 67. 
pogranicze także w sensie symbolicznym, określającym filary tożsamości współegzystujących tam grup społecznych. Tożsamości zbudowanej na osobnych fundamentach aksjonormatywnych, ale także stale konstruowanej, inkluzyjnie łączącej różne elementy. Said Saddiki słusznie zauważa, że casus ten obrazuje styczność definiowaną przez wiele odmienności: religijną, regionalną, etniczną i narodową, a także widoczną w relacjach państwa niegdyś kolonialnego z obszarem relatywnie od niedawna cieszącym się prawem do stanowienia ${ }^{39}$.

Islam, obecny przez wiele wieków na Półwyspie Iberyjskim, w dużym stopniu ukształtował kulturę tego obszaru, choć stulecia konfliktów przyczyniły się do powstania wizerunku barbarzyńskiego „Maura” (moro), przed którym należało się strzec. Szereg badań ukazuje, że muzułmanie często doświadczają uprzedzeń, są postrzegani przez negatywne stereoty$\mathrm{py}^{40}$. Zwiększający się od lat 90. XX w. napływ do Hiszpanii imigrantów wyznających islam, wywodzących się szczególnie z regionu Maghrebu, przyczynił się do krystalizacji społeczeństwa wielokulturowego o różnym wachlarzu postaw zarówno wśród rdzennej jego części populacji, jak i imigrantów oraz ich kolejnych pokoleń, doświadczających akceptacji, ale także stygmatyzacji i uprzedzeń. Procesy te doprowadziły do tego, że „imigracja przesunęła się w Hiszpanii ku centrum dyskursu publicznego, podkreśla się konieczność podejmowania działań mających na celu ułatwienie integracji imigrantów na podstawie symbolicznego wymogu poszanowania zarówno obyczajów ludności goszczącej, jak i tych charakterystycznych dla przybyszów"

Wielokulturowość rodzi nieuchronnie pytania o tożsamość społeczności żyjących wspólnie na jednym obszarze, szczególnie na pograniczu, w sytuacji wzajemnych interakcji, które mogą mieć charakter więziotwórczy bądź antagonistyczny. Ceuta i Melilla w istotnym zakresie obrazują te zależności, zważywszy na ich szczególne położenie oraz „tkankę społeczną”, która je tworzy. Jakkolwiek istnieją liczne problemy o charakterze społeczno -ekonomicznym, praktyka ostatnich lat wskazuje na możliwość stabilnej koegzystencji społeczności o różnym rodowodzie etnokulturowym, która niekoniecznie musi oznaczać integrację w sensie amalgamacji kulturowej. Czy równowaga ta okaże się stabilna, czy ziszczą się kasandryczne prognozy „marokanizacji” i „berberyzacji” tych ośrodków, trudno jest jednoznacznie prognozować. $Z$ pewnością wiele zależy od kształtu stosunków hiszpańskomarokańskich, ale także od inicjatyw władz lokalnych i wdrażanych progra-

39 S. Saddiki, op. cit., s. 84.

${ }^{40}$ Por. M. Biernacka, op. cit., s. 186-191; Islamofobia en España 2017, Informe Anual, Plataforma Ciudadana contra la Islamofobia, Febrero 2018, s. 15-18.

${ }^{41}$ Ibidem, s. 9. 
mów inkluzji społecznej oraz procesów migracyjnych i demograficznych, które mogą okazać się w tym kontekście kluczowe.

\section{Bibliografia}

2.250 inmigrantes entraron en Ceuta ilegalmente desde Marruecos en 2017, „La Gaceta" 5 de enero de 2018.

Adlbi Sibai S., 'Sometimes I'm Spanish and sometimes not': a study of the identity and integration of Spanish Muslim women, „Research in Comparative and International Education" Vol. 5, No. 2/2010, DOI: https://doi. org/10.2304/rcie.2010.5.2.185.

Alvarado D., La yihad a nuestras puertas. La amenaza de Al Qaeda en el Maghreb Islámico, Foca, Madrid 2010.

Biernacka M., Hiszpania wielokulturowa. Problemy z odmiennościq, Scholar, Warszawa 2012.

Blickman T., Morocco and Cannabis. Reduction, containment or acceptance, „Drug Policy Briefing” 2017, https://www.researchgate.net/ publication/316104129_Morocco_and_Cannabis_Reduction_containment_or_acceptance (dostęp 20.04.2019).

Casella $\bar{B} ., \bar{M}$ orocco, Ceuta and Melilla: a failed immigration policy, „Mediterranean Affairs" December 3, 2014.

Castan Pinos J., Identity Challenges Affecting the Spanish Enclaves of Ceuta and Melilla, „Nordlit” No. 13 (1)/2009, DOI: https://doi. org/10.7557/13.1468.

Ceuta y Melilla celebran ser un "ejemplo" de convivencia con la fiesta de sacrifcio, „El Mundo” 17 de noviembre de 2011.

Ceuta y Melilla plantean negar la nacionalidad española a los hijos de inmigrantes, „Vozpopuli” 17 de febrero de 2019.

Ceuta y Melilla ya están marroquinizadas y van hacia el choque con España, „El Brief de Actuall”, https://www.actuall.com/democracia/ceuta-ymelilla-ya-estan-marroquinizadas-y-van-hacia-el-choque-con-espana/ (dostęp 14.08.2019).

Ceuta y Melilla: un teritorio sin derechos para personas migrantes y refugiadas, Amnistía Internacional, 26 de noviembre de 2016, https://www. es.amnesty.org/en-que-estamos/noticias/noticia/articulo/ceuta-y-melilla-un-territorio-sin-derechos-para-personas-migrantes-y-refugiadas/ (dostęp 17.08.2019).

Dominguez Diaz M., The struggle to be seen: Muslim-Christian relations and religious (in)visibility at the Hispano-Moroccan borderland, "Journal of Contemporary Religion” Vol. 33, Issue 3/2018, DOI: https://doi.org /10.1080/13537903.2018.1542863. 
Ferenc T., Ceuta - afrykańskie wrota do Europy, „Pogranicze - Polish Borderlands Studies" t. 6, nr 2/2018.

Ferrer-Gallardo X., Planet-Contreras A., Cetua and Melilla: Euro-African Borderscapes, „AGORA” No. 4/2012, DOI: https://doi.org/10.21825/ agora.v28i4.2397.

Gold P., Europe or Africa? A Contemporary Study of the Spanish North Africa Enclaves of Ceuta and Melilla, Liverpool University Press, Liverpool 2000, DOI: https://doi.org/10.5949/UPO9781846313066.

González-Enríquez C., Pérez González Á., Ceuta y Melilla: nuevos elementos en el escenario, Real Instituto Elcano, „ARI” 4 de diciembre de 2008.

Islamofobia en España 2017, Informe Anual, Plataforma Ciudadana contra la Islamofobia, Febrero 2018.

Kosmynka S., The Role of Moroccan Salafist Radicalism in Creating Threat to Spain's Security, „Politeja” nr 42/2016, DOI: https://doi.org/10.12797/ Politeja.13.2016.42.11.

Kosmynka S., Zapobieganie radykalizacji jako element strategii antyterrorystycznej wtadz Hiszpanii, w: Międzynarodowe oblicza terroryzmu. Ujęcie interdyscyplinarne, red. T. Domański, Wydawnictwo Uniwersytetu Łódzkiego, Łódź 2017.

La población musulmana en España, Fundación „Forum Libertas” 29 de agosto de 2017.

López Bueno J.M., Melilla: lecciones inadvertidas de integración, Real Instituto Elcano, „ARI” 20 de octubre de 2010.

Macarrón A., Melilla y nuestro suicidio demográfico, „Libertad digital” 6 de septiembre de 2010, http://www.libertaddigital.com/opinion/alejandro-macarron/melilla-y-nuestro-suicidio-demografico-56115/ (dostęp 30.03.2013).

Mesa García B., Ceuta y Melilla: una visión de futuro, Instituto Español de Estudios Estratégicos, „Documento de Opinión” No. 3/2012.

Moral P., Ceuta y Melilla, la excepción española, https://elordenmundial. com/ceuta-y-melilla-la-excepcion-espanola/ (dostęp 14.08.2019).

Nikitorowicz J., Pogranicze. Tożsamość. Edukacja międzykulturowa, Trans Humana, Białystok 1995.

Planet-Contreras A., Melilla y Ceuta. Espacios-frontera hispano-marroquies, Servicio de Publicaciones, Melilla 1998.

Reinares F., García-Calvo C., Vicente Á., Dos factores que explican la radicalización yihadista en España, Real Instituto Elcano de Estudios Internacionales y Estratégicos, „ARI” 8 de agosto de 2017.

Relaciones hispano-marroquies: una vecindad en construcción, red. A. Planet Contreras, F. Ramos, Ediciones del Oriente y del Mediterráneo, Madrid 2005. 
Saddiki S., World of Walls. The Structure, Roles and Effectiveness of Separation Barriers, Open Book Publishers, Cambridge 2017, DOI: https:// doi.org/10.11647/OBP.0121.

Soddu P., Ceuta and Melilla: Security, Human Rights and Frontier Control, "Culture and Society" 2006.

Una Universidad busca prevenir que jóvenes de Melilla no caigan en manos del yihadismo, „Melilla Hoy” 19 de enero de 2015.

Valle del A., Ceuta, Melilla, Chafarinas, Vélez y Alhucemas: tomar la iniciativa, Real Instituto Elcano de Estudios Internacionales y Estratégicos, „ARI” 20 de diciembre de 2011. 